\title{
Pembelajaran Kewirausahaan Daring pada Masa Pandemi Covid-19
}

\author{
Online Entrepreneurship Learning during the Covid-19 Pandemic
}

Rani Novitasari ${ }^{1}$, Indri Murniawaty ${ }^{2}$, Siti Listyaningsih ${ }^{3}$, Dwi Puji Astuti ${ }^{4}$, Ahmad Sehabuddin $^{5}$

1, 2, 3, 4, 5 Pendidikan Ekonomi, Fakultas Ekonomi, Universitas Negeri Semarang

\begin{tabular}{l} 
ARTICLE INFO \\
\hline Article history: \\
DOI: \\
10.30595/pssh.v1i.72 \\
Submitted: \\
April 12, 2021 \\
Accepted: \\
June 10, 2021 \\
Published: \\
June 14, 2021 \\
Keywords: $\quad$ Entrepreneurship, \\
Learning, Online Readiness
\end{tabular}

Corresponding Author:

Siti Listyaningsih

Pendidikan Ekonomi,

Fakultas Ekonomi, Universitas Negeri Semarang

Gedung L3 Lantai 1 FE UNNES

Kampus Sekaran, Gunungpati, Semarang, 50229

Email: listian71@gmail.com License.

\begin{abstract}
One solution to reduce unemployment is to create an entrepreneur in vocational school students through entrepreneurship learning. Efforts to prevent the spread of the Corona Virus in Indonesia have resulted in entrepreneurship learning being carried out online. The purpose of this study was to determine the implementation of online entrepreneurship learning, the obstacles faced when implementing online entrepreneurship learning and the strategies of the obstacles associated with learning entrepreneurship online at SMK YPPM, Boja District, Kendal Regency. The method used in this research is descriptive qualitative with data collection techniques, namely interviews, questionnaires with a Likert scale, and documentation. The results of this study are (1) Online entrepreneurship learning shows ineffective results. (2) The obstacles that arise during the implementation of online entrepreneurship learning for students are students who are not ready, unhappy, not interested in online entrepreneurship learning, lack of understanding of online learning media, inadequate internet networks, difficulty finding learning resources, unaccompanied, students cannot concentrate, students feel lazy, bored when learning entrepreneurship online and after learning entrepreneurship online students do not like reading books. Meanwhile, the obstacle for teachers is that it is difficult for teachers to find student grades because there are still many who do not collect assignments. (3) The strategy to reduce barriers is for the teacher to conduct a home visit. Shows very effective results and runs smoothly.
\end{abstract}

This work is licensed under a Creative Commons Attribution 4.0 International

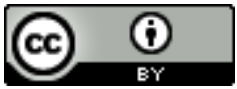

\section{PENDAHULUAN}

Pengangguran merupakan masalah besar di Indonesia. Jumlah pengangguran di Indonesia setiap tahun mengalami peningkatan. Hal tersebut berdampak pada masalah-masalah lain seperti kemiskinan dan kesenjangan sosial. Berdasarkan data statistik mencatat jumlah mengalami kenaikan 50 ribu orang per Agustus tahun 2019. [1] Tingkat pengangguran tertinggi masih berasal dari lulusan Sekolah Menengah Kejuruan sebesar 10,42\%. Padahal lulusan SMK lebih berpotensi bekerja dibandingkan lulusan SMA, oleh karena itu lulusan SMK diharapkan menyiapkan diri agar setelah lulus dapat bekerja. Di samping lulusan SMK juga harus kreatif karena lapangan pekerjaan di Indonesia masih sangat terbatas belum lagi karena wabah Covid-19, lapangan pekerjaan yang tersedia akan semakin sempit pada masa mendatang.

[2] Salah satu solusi yang ditempuh untuk mengatasi pengangguran di Indonesia adalah dengan menciptakan wirausaha. Untuk mengurangi angka pengangguran dapat diperkecil dengan keberanian membuka usaha-usaha baru 
atau berwirausaha. Selain berpeluang menghasilkan pendapatan yang besar, berwirausaha juga mampu membantu pemerintah mengurangi jumlah pengangguran dengan menciptakan lapangan pekerjaan baru. Lapangan pekerjaan yang tersedia akan semakin sempit pada masa mendatang. Jumlah pengangguran dan kemiskinan dapat diperkecil dengan keberanian membuka usaha-usaha baru atau berwirausaha.

Pendidikan di Indonesia untuk saat ini lebih banyak mengedepankan penguasaan aspek keilmuan, kecerdasan dan mengabaikan pendidikan karakter. Sementara, pengetahuan tentang kaidah moral yang didapatkan dalam pendidikan moral atau etika di sekolah semakin ditinggalkan. Pelaksanaan pendidikan untuk saat ini banyak yang kurang memperhatikan lagi bagaimana pendidikan dapat lebih berdampak terhadap perilaku seseorang. Perilaku seseorang akan mencerminkan bagaimana pendidikan yang telah didapatkan. [3] Kewirausahaan awalnya hanya dipandang sebagai kemampuan yang dilahirkan dari pengalaman langsung di lapangan. Kewirausahaan juga merupakan bakat yang dibawa sejak lahir sehingga kewirausahaan tidak dapat dipelajari dan diajarkan. Namun sekarang ini kewirausahaan bukan hanya bakat bawaan sejak lahir atau urusan pengalaman lapangan, tetapi juga dapat dipelajari dan diajarkan. Kewirausahan tidak selalu identik dengan perilaku watak pengusaha saja karena sifat ini juga dimiliki oleh mereka yang bukan pengusaha seperti petani, pns, mahasiswa, siswa, dan lain-lain yang dilakukan secara kreatif dan inovatif.

[4] Kewirausahaan merupakan proses penciptaan sesuatu yang baru, kreasi baru, dan membuat sesuatu yang berbeda dari yang telah ada/inovasi, tujuannya adalah tercapainya kesejahteraan individu dan nilai tambah bagi masyarakat. Kewirausahaan memiliki peran penting dalam kehidupan dan pembangunan suatu negara. Kewirausahaan terbukti dapat memperluas lapangan pekerjaan sehingga dapat menyerap tenaga kerja yang ada. [5] Selain itu, dalam jangka panjang dapat menstabilkan perekonomian sebagai dampak dari pertumbuhan usaha baru di berbagai bidang. Berkaitan dengan hal tersebut, komitmen untuk menciptakan seorang wirausaha dapat dimulai melalui pembelajaran kewirausahaan. [6] Menciptakan seorang wirausaha dapat dimulai melalui pembelajaran kewirausahaan yang diajarkan guru di kelas. Pembelajaran kewirausahaan diharapkan mampu membangkitkan semangat berwirausaha, berdikari, berkarya dan mengembangkan perekonomian nasional.

Pada dasarnya pembelajaran merupakan salah satu solusi yang cukup berperan dalam mengatasi berbagai masalah yang terjadi di Indonesia, khususnya yaitu masalah ketenagakerjaan yang hingga kini masih menjadi tugas kita bersama. Pendidikan yang baik akan menciptakan sumber daya manusia yang dapat bersaing secara kompetitif. [7] Untuk menjadi seorang wirausaha melalui suatu proses yaitu mulai dari perubahan jadi diri, pola pikir serta cara melakukan atau mengerjakan sesuatu. Proses untuk menjadi wirausaha beraneka ragam, misalnya terjadi karena dibentuk lewat proses pendidikan formal/informal (pelatihan, workshop, pelatihan khusus, pendidikan bidang khusus seperti manajemen, bisnis, akuntansi, kewirausahaan dan lain-lain). [8] Tujuan pembelajaran kewirausahaan antara lain: (1) membentuk jiwa wirausaha peserta didik, sehingga yang bersangkutan menjadi individu yang kreatif, inovatif, dan produktif; (2) menanamkan nilai-nilai kewirausahaan pada siswa; (3) melatih keterampilan berwirausaha kepada siswa melalui praktik berwirausaha; (4) memberikan bekal pengetahuan berwirausaha.

Pembelajaran merupakan salah satu solusi yang cukup berperan dalam mengatasi berbagai masalah yang terjadi di Indonesia, khususnya yaitu masalah ketenagakerjaan yang hingga kini masih menjadi tugas kita bersama. Menteri Pendidikan dan Kebudayaan mengeluarkan Surat Edaran No 3 tahun 2020 tentang pelaksanaan kegiatan pembelajaran untuk pencegahan penyebaran virus Covid-19 pada Satuan Pendidikan. Penyebaran virus Corona (Covid-19) di Indonesia telah merubah tatanan kehidupan masyarakat, tidak hanya menyerang negara Indonesia namun juga melanda dunia. Keberadaan Covid-19 membuat masyarakat untuk memberhentikan aktivitas di luar rumah. Masyarakat harus menjaga jarak aman atau physical distancing.

Pelaksanaan karantina dan isolasi mandiri yang dihimbau oleh pemerintah berdampak pada sistem pendidikan.

Proses pembelajaran yang mana biasa dilaksanakan secara tatap muka di dalam ruang kelas pada lingkungan sekolah, kini berubah menjadi dengan belajar di dalam rumah atau daring. Kondisi ini tentu tidak mudah dilalui, di mana tugas yang diberikan oleh guru sebagai kegiatan memindahkan aktivitas kelas dari belajar di sekolah menjadi belajar di rumah dibebankan pada siswa bahkan lebih banyak. [9] Media pembelajaran dimaksudkan merupakan salah satu alat komunikasi dalam proses pembelajaran, dikatakan demikian karena di dalam proses pembelajaran terdapat proses penyampaian pesan dari pendidik kepada anak didik.

[10] Media pembelajaran diartikan sebagai salah satu faktor eksternal yang berpengaruh terhadap keberhasilan kegiatan pembelajaran, secara umum manfaat media pembelajaran yakni untuk memperlancar interaksi antar guru dengan siswa sehingga pembelajaran lebih efektif dan efisien. Selain media pembelajaran memerlukan kesiapan gadget berupa smartphone, laptop, atau komputer dan tentu paket data internet yang masih dikelola secara mandiri. Sesuai Permendikbud no 34 Tahun 2018, pendidikan kejuruan merupakan pendidikan menengah yang mempersiapkan peserta didik terutama untuk bekerja dalam bidang tertentu. Pada pendidikan kejuruan memberikan suatu bentuk pengembangan bakat, pendidikan dasar keterampilan dan kebiasaan- kebiasaan yang mengarah pada dunia kerja yang dipandang sebagai latihan keterampilan. Siswa akan disiapkan untuk memasuki persaingan di dunia kerja.

Dari data jumlah SMK di Indonesia, Jawa Tengah merupakan salah satu provinsi dengan jumlah SMK terbanyak. [11] Jumlah SMK di Jawa Tengah adalah 2.937 yang terdiri 287 negeri dan 2.650 swasta. Salah satu SMK 
di Jawa Tengah yaitu SMK YPPM BOJA merupakan salah satu SMK tertua yang berada di Kecamatan Boja Kabupaten Kendal dan memiliki pernah meraih juara 1 Pemaparan Produk Tingkat Kabupaten tahun 2017 dan juara 1 LKS Pemasaraan Tingkat Kabupaten tahun 2019.

Tabel 1.1

Jumlah Siswa SMK YPPM Boja

\begin{tabular}{|c|c|c|c|c|}
\hline No & Uraian & Detail & Jumlah & Total \\
\hline \multirow[t]{3}{*}{1.} & \multirow{3}{*}{ Kelas 10} & AKL & 24 & \multirow{3}{*}{60} \\
\hline & & OTKP & 15 & \\
\hline & & TB & 21 & \\
\hline \multirow[t]{3}{*}{2.} & \multirow[t]{3}{*}{ Kelas 11} & AKL & 16 & \multirow{3}{*}{56} \\
\hline & & OTKP & 21 & \\
\hline & & TB & 19 & \\
\hline \multirow[t]{3}{*}{3.} & \multirow[t]{3}{*}{ Kelas 12} & $\mathrm{AKL}$ & 16 & \multirow{3}{*}{50} \\
\hline & & OTKP & 13 & \\
\hline & & TB & 21 & \\
\hline \multicolumn{4}{|c|}{ Total siswa } & 166 \\
\hline
\end{tabular}

Sumber: SMK YPPM Boja

Hasil wawancara dengan guru kewirausahaan di SMK YPPM Boja pembelajaran mata pelajaran kewirausahaan daring diberlakukan hanya di kelas 11 dan 12 di jadwalkan pada setiap hari kamis seminggu 2 kali. Pembelajaran mata pelajaran kewirausahaan yang dilaksanakan secara daring/online berjalan kurang lancar dan tidak efektif. Guru dan siswa masih banyak mengalami kendala seperti: (1) Guru mengalami kesulitan mencari nilai siswa karena masih banyak siswa yang tidak bisa hadir/tidak dapat mengikuti pembelajaran secara daring, bahkan masih banyak siswa yang tidak mengerjakan tugas/mengumpulkan tugas yang diperintahkan oleh guru. (2) Siswa masih banyak mengalami kesulitan-kesulitan seperti sinyal karena jangkauan sinyal masing-masing daerah berbeda. Sehingga masih banya banyak siswa yang tidak mengerjakan tugas atau mengumpulkan tugas kepada guru.

Data yang dicatat oleh guru BK bahwa lulusan SMK YPPM Boja yang diketahui bahwa 3 tahun terakhir ini rata-rata bekerja menjadi karyawan perusahaan-perusahaan/pabrik, jaga toko seperti Indomaret dan Alfamart, bengkel, cuci motor dan mobil dan banyak pula yang masih menganggur. Berikut merupakan gambaran persentase data pekerjaan lulusan SMK YPPM Boja yang dicatat guru BK pada lulusan tahun 2019, 2018 dan 2017 disajikan sebagai berikut:

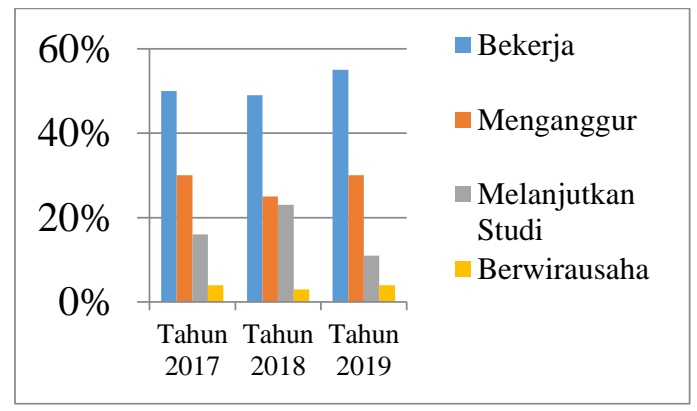

Gambar 1.1 Diagram Pekerjaan Alumni SMK YPPM Boja

Sumber: Data BKK SMK YPPM Boja tahun 2020

Terlihat dari Gambar 1.1 bahwa lulusan SMK YPPM Boja setiap tahunnya siswa lebih banyak bekerja dan jumlah lulusan yang berwirausaha setiap tahunnya masih sangat kurang karena baru mencapai $3 \%$ dan $4 \%$ yang menjadi wirausaha dibandingkan jumlah lulusan yang bekerja dan melanjutkan sekolah tinggi. Faktor yang mempengaruhi berwirausaha banyak siswa yang tidak tertarik karena membutuhkan modal yang cukup dan kurangnya motivasi. Berdasarkan data diatas maka peneliti memfokuskan pada pembelajaran kewirausahaan yang dilakukan secara daring.

Perkiraan pada tahun mendatang kemungkinan jumlah lapangan pekerjaan yang ada jumlahnya terbatas, tidak sesuai dengan orang yang mencari pekerjaan atau jumlah tenaga kerja berkurang drastis karena pandemi Covid-19. Hal ini akan memperbanyak jumlah pengangguran, solusi untuk mengatasinya lebih memprioritaskan pembelajaran kewirausahaan yang mampu menyiapkan SDM maupun lulusan berkualitas dan mampu berdaya saing di era globalisasi.

Berdasarkan latar belakang penelitian ini, maka permasalahan yang ingin dibahas dapat dirumuskan sebagai berikut: (1) Bagaimana pelaksanaan pembelajaran kewirausahaan secara daring pada masa pandemi Covid-19 di SMK YPPM Kecamatan Boja Kabupaten Kendal? (2) Apa hambatan yang muncul saat pelaksanaan pembelajaran 
kewirausahaan secara daring pada masa pandemi Covid-19 di SMK YPPM Kecamatan Boja Kabupaten Kendal? (3) Bagaimana strategi dari hambatan yang terkait saat pembelajaran kewirausahaan daring pada masa pandemi Covid19 di SMK YPPM Kecamatan Boja Kabupaten Kendal?

\section{METODE PENELITIAN}

Penelitian yang digunakan dalam penelitian ini adalah metode deskriptif dengan pendekatan kualitatif. [12] Penelitian kualitatif untuk memahami fenomena tentang apa yang dialami oleh subjek penelitian. Metode ini relevan dan sesuai dengan penelitian ini untuk pemahaman mengenai pembelajaran kewirausahaan daring dalam menumbuhkan kesiapan berwirausaha. Penelitian ini yang menjadi fokus permasalahan yang akan diteliti adalah eksplorasi pembelajaran kewirausahaan daring dalam menumbuhkan kesiapan berwirausaha di SMK YPPM Boja. Untuk mendapatkan data tersebut dipergunakan dalam penelitian ini: (1) Wawancara, (2) Dokumentasi, (3) Kuesioner.

Wawancara digunakan untuk mendapatkan data Profil, sejarah SMK YPPM Boja serta informasi siswa dan guru SMK YPPM Boja. Dan Informasi mengenai pelaksanaan, hambatan dan strategi pembelajaran kewirausahaan daring untuk mengetahui pembelajaran kewirausahaan daring yang diajarkan guru dan respon siswa. Dokumentasi penelitian ini berbentuk foto, rekaman dan buku catatan. Kuesioner digunakan untuk mendapatkan data dari responden mengenai pelaksanaan pembelajaran kewirausahaan daring dan hambatannya. Populasi dari penelitian ini adalah seluruh siswa kelas 12 SMK YPPM Boja, Kabupaten Kendal yang berjumlah 50 siswa. Alasan peneliti mengambil populasi siswa kelas 12 karena siswa kelas 12 akan lulus dan mencari pekerjaan dan telah mengikuti pembelajaran kewirausahaan serta pengalaman yang cukup di kelas sebelumnya yaitu kelas 11 untuk mengetahui perbedaanperbedaan pembelajaraan kewirausahaan daring dengan pembelajaran kewirausahaan di kelas. Sehingga siswa kelas 12 akan lebih baik jika dibandingkan dengan kelas 10 dan kelas 11. Skala yang digunakan untuk mengukur penelitian ini adalah skala Likert $1-4$. Terdiri dari 22 butir pernyataan.

Teknik analisis data menggunakan model Miles dan Huberman yaitu reduksi data, penyajian data dan penarikan kesimpulan. Pengambilan data didalam penelitian ini dimulai dari awal penelitian hingga akhir penelitian. Pengambilan data dilakukan selama tiga bulan. Saat mendapatkan data, peneliti langsung mencatat dan merangkum hasil dari data yang diperoleh. Dalam mereduksi data pada penelitian ini, peneliti akan memfokuskan pada proses pelaksanaan pembelajaran kewirausahaan. Selain itu, peneliti dipandu oleh tujuan yang akan dicapai. Tujuan utama dalam penelitian ini adalah menemukan hambatan dan strategi pelaksanaan pembelajaran kewirauhaan secara daring dalam menumbuhkan kesiapan berwirausaha. Selama penelitian, peneliti mencatat, memilih dan mengelompokkan hasil-hasil wawancara agar siap untuk disajikan. Penyajian data dilakukan selama penelitian berlangsung. Data-data yang sudah dirangkum didalam reduksi data, selanjutnya di sajikan. Berdasarkan data yang telah direduksi mengenai hambatan pembelajaran kewirauahaan daring, ditemukan bahwa siswa banyak yang mengalami kesulitan dan tidak tertarik dengan adanya pembelajaran kewirausahaan daring.

Data ini ditemukan melalui wawancara kepada guru kewirausahaan di SMK YPPM Boja dan kuesioner kepada semua siswa kelas 12 yang mengikuti pembelajaran kewirausahaan daring dalam menumbuhkan kesiapan berwirausaha. Temuan ini meliputi siswa tidak siap, tidak senang, tidak tertarik dengan pembelajaran kewirausahaan daring dibuktikan dengan dokumentasi berupa foto saat siswa banyak tidak mengerjakan atau mengumpulkan tugas. Langkah selanjutnya setelah mereduksi data dan menyajikan data adalah penarikan kesimpulan. Berdasarkan data yang telah direduksi dan di sajikan, ditemukan bahwa dengan adanya pembelajaran kewirausahaan daring ini, kesiapan berwirausaha di SMK YPPM menjadi tidak semakin berkembang. Dibuktikan dengan data yang ada.

\section{HASIL DAN PEMBAHASAN}

SMK YPPM Boja merupakan SMK yang terletak di Jalan Raya Bebengan no. 122, RT/RW 4/6, Desa Bebengan, Kecamatan Boja Kabupaten Kendal Jawa tengah. SMK YPPM Boja merupakan SMK tertua di kecamatan Boja yang didirikan tanggal 29 Februari 1973. Visi dari SMK YPPM "Menjadi lembaga yang berstandar untuk mewujudkan sumber daya manusia yang cerdas, terampil, kompetitif, berakhlak Mulia". Jadi siswa lulusan SMK YPPM diharapkan dapat menjadi sumber daya manusia yang berkualitas dan memiliki sikap berakhlak mulia. Misi SMK YPPM yaitu sebagai berikut: (a) Melaksanakan Sistem Pendidikan Nasional, (b) Meningkatkan Mutu Tenaga Pendidik dan Kependidikan, (c) Menjalin Kemitraan dengan DU/DI, (d) Mengoptimalkan peran serta masyarakat dalam pengembangan sekolah, (e) Meningkatkan keharmonisan dan kesejahteraan, (e) Meningkatkan kegiatan keagamaan.

SMK YPPM (Yayasan Pembinaan Pembangunan Masyarakat) Boja Kendal di tahun pelajaran 2019/2020 mempunyai guru, tenaga administrasi/karyawan SMK sebanyak yang terdiri dari 23 orang guru, 1 orang staf Kabag TU, 1 orang staf Bendahara, 1 orang staf Administrasi, 1 orang operator dan pengelola perpustakaan, 2 orang prakarya Kebun, 1 orang penjaga sekolah, 2 orang penjaga malam, 1 orang satpam, 3 orang yayasan. Siswa SMK YPPM Boja ini berjumlah 166 siswa, yang terdiri dari 54 siswa dan 112 siswi. Program Keahlian di SMK YPPM Boja ada 3 yaitu Akuntansi Keuangan Lanjutan (AKL), Otomatisasi Tata Kelola Perkantoran (OTKP), dan Tata Busana (TB).

Pelaksanaan pembelajaran daring mata pelajaran kewirausahaan di SMK YPPM Boja dimulai tanggal 23 Juli 2020, sesuai jadwal yang sudah ditentukan pembelajaran mata pelajaran kewirausahaan secara daring dilakukan setiap 
dua minggu sekali. Jadwal yang sudah ditentukan tersebut sehari hanya untuk satu mata pelajaran, agar siswa dapat fokus dan konsentrasi dengan satu mata pelajaran setiap harinya dengan menggunakan media pembelajaran daring yang dapat dimanfaatkan dalam pembelajaran jarak jauh (PJJ). Pembelajaran di rumah secara daring dapat menggunakan gawai (gadget) maupun laptop melalui beberapa portal dan aplikasi pembelajaran daring.

Pembelajaran kewirausahaan daring di SMK YPPM Boja dilaksanakan pertama kali dengan menggunakan media pembelajaran via Google Classrom, Zoom, Moodle, dan WhatsApp. Namun media pembelajaran daring yang efektif hanya menggunakan Moodle dan WhatsApp. Moodle merupakan perangkat lunak yang diciptakan untuk aktivitas pembelajaran daring menggunakan internet dan website. Fitur yang dapat dilakukan forum diskusi, pengumpulan tugas, kuis, chatting, unduhan arsip, dan berita. Sesuai hasil wawancara tersebut guru kewirausahaan menuturkan bahwa siswa kurang paham media pembelajaran daring. Diperkuat dengan hasil jawaban responden dari siswa mengenai Media yang digunakan saat pembelajaran daring mata pelajaran kewirausahaan mudah untuk dipahami sebesar 49\% dengan kriteria rendah yang artinya siswa kelas 12 SMK YPPM kurang paham media pembelajaran online yang digunakan saat pembelajaran kewirausahaan secara daring.

Pembelajaran kewirausahaan secara daring siswa diberi materi dan tugas. Materi kewirausahaan yang diajarkan pada kelas 12 semua jurusan di SMK YPPM Boja saat pembelajaran daring dengan tematik 4 yaitu Produk Kreatif dan Kewirausahaan. Pembelajaran kewirausahaan secara daring dilaksanakan dengan menyusun perencanaan dan pelaksanaan pembelajaran. Perencanannya guru membuat materi, tugas dan soal evaluasi, sedangkan pelaksanaannya guru menugaskan siswa untuk menganalisis atau merangkum yang sudah dibagikan ke grup WhatsApp dan Moodle. Berupa teks, video mengenai kewirausahaan. Kemudian hasil karya atau tugas siswa dikirim dalam bentuk foto ke media yang sudah disepakati atau langsung ke media Moodle dalam bentuk softfile Microsoft Word sesuai yang diperintahkan.

Pembelajaran kewirausahaan secara daring sudah berlangsung sebanyak 11 kali pertemuan, ketika peneliti melakukan wawancara pada tanggal 30 November 2020 dan siswa SMK YPPM Boja sangat bersemangat dan tertarik dengan kegiatan kewirausahaan. Diperkuat dengan hasil jawaban responden dari siswa mengenai siswa senang dan tertarik ketika melakukan kegiatan kewirausahaan sebesar 83,5\% dengan kriteria sangat tinggi yang artinya siswa kelas 12 SMK YPPM sangat senang dan tertarik dengan kegiatan kewirausahaan.

Sebelum diadakannya pembelajaran daring siswa lebih mudah memahami mengenai kewirausahaan karena kewirausahaan itu pelajaran yang tidak membosankan siswa. Diperkuat dengan hasil jawaban responden dari siswa mengenai siswa memahami dengan baik tentang kewirausahaan sebesar 74,5\% dengan kriteria tinggi yang artinya siswa kelas 12 SMK YPPM Boja memahami dengan baik tentang kewirausahaan. Siswa tidak mengalami kesulitan saat pembelajaran kewirausahaan sebelum diadakannya pembelajaran daring, siswa malah sangat senang ketika ada jam mata pelajaran kewirausahaan. Diperkuat dengan hasil jawaban responden dari siswa mengenai siswa tidak mengalami kesulitan saat pembelajaran kewirausahaan sebesar 70\% dengan kriteria tinggi yang artinya siswa kelas 12 SMK YPPM Boja tidak mengalami kesulitan ketika pembelajaran kewirausahaan berlangsung.

Hasil angket mengenai setelah mengikuti pembelajaran kewirausahaan siswa yakin menjadi wirausahawan yang sukses sebesar $83 \%$ dengan kriteria sangat tinggi yang artinya siswa kelas 12 SMK YPPM Boja sangat yakin menjadi wirausahawan setelah mengikuti pembelajaran kewirausahaan. Kemudian mengenai setelah menerima pembelajaran kewirausahaan siswa ingin berwirausaha setelah lulus SMK sebesar 80\% dengan kriteria tinggi yang artinya siswa kelas 12 SMK YPPM Boja setelah menerima pembelajaran kewirausahaan siswa ingin berwirausaha setelah lulus SMK. Hasil angket tersebut menyatakan bahwa siswa sangat senang dan tertarik dengan kegiatan kewirausahaan, setelah mengikuti pembelajaran kewirausahaan dan setelah siswa lulus dari SMK siswa sangat yakin menjadi wirausahawan.

Setelah diadakannya pembelajaran kewirausahaan secara daring, siswa tidak senang dan tidak tertarik dengan pembelajaran kewirausahaan secara daring Diperkuat dengan hasil jawaban responden dari siswa mengenai siswa senang dan tertarik dengan pembelajaran kewirausahaan secara daring sebesar $49,5 \%$ dengan kriteria rendah yang artinya siswa kelas 12 SMK YPPM Boja tidak senang dan tidak tertarik dengan pembelajaran kewirausahaan secara daring atau siswa lebih tertarik melaksanakan pembelajaran kewirausahaan di sekolah. Hasil angket mengenai siswa dapat berpikir kreatif saat pembelajaran kewirausahaan secara daring sebesar 66,5\% dengan kriteria tinggi yang artinya siswa kelas 12 SMK YPPM Boja dapat berpikir kreatif meskipun pembelajaran kewirausahaan dilaksanakan secara daring.

Hambatan yang dialami guru saat pembelajaran kewirausahaan secara daring adalah pernilaian siswa karena masih banyak siswa yang tidak mengerjakan tugas, tidak mengumpulkan tugas dan sulit dihubungi dengan alasan siswa tidak memiliki jaringan internet. Diperkuat dengan hasil jawaban responden dari siswa mengenai siswa memiliki perangkat digital (HP, Laptop, dst) saat pembelajaran daring mata pelajaran kewirausahaan sebesar $71 \%$ dengan kriteria tinggi yang artinya siswa kelas 12 SMK YPPM Boja memiliki modal HP atau laptop untuk menunjang saat pembelajaran kewirausahaan secara daring.

Hasil angket mengenai siswa yang tidak memiliki jangkauan jaringan internet saat pembelajaran kewirausahaan secara daring. Diperkuat dengan hasil jawaban responden dari siswa mengenai siswa memiliki jaringan internet saat pembelajaran daring mata pelajaran kewirausahaan sebesar $49 \%$ dengan kriteria rendah yang artinya 
siswa kelas 12 SMK YPPM Boja tidak memiliki jaringan internet saat pembelajaran kewirausahaan secara daring, sehingga siswa sulit mengirim atau mengumpulkan tugas mereka kepada guru. Hasil angket mengenai siswa memiliki jaringan listrik saat pembelajaran kewirausahaan secara daring sebesar 67,5\% dengan kriteria tinggi yang artinya siswa kelas 12 SMK YPPM Boja memiliki jaringan listrik saat pembelajaran kewirausahaan secara daring.

Siswa kelas 12 SMK YPPM Boja rata-rata mengalami kesulitan mencari sumber belajar kewirausahaan saat pembelajaran kewirausahaan secara daring. Diperkuat dengan hasil jawaban responden dari siswa mengenai siswa mudah mendapatkan sumber belajar kewirausahaan selama proses belajar dari rumah sebesar $49 \%$ de]ia rendah. Sehingga banyak siswa yang tidak mengerjakan tugas karena rata-rata siswa kesulitan mencari sumber belajar untuk mengerjakan tugas kewirausahaan saat pembelajaran kewirausahaan daring, maka guru juga kesulitan mendapatkan nilai dari siswa yang tidak mengerjakan dan tidak mengumpulkan tugas kewirausahaan. Siswa dapat mengatur waktu untuk mengerjakan tugas, karena pembelajaran kewirausahaan secara daring bisa dikerjakan kapan saja karena lebih praktis dan fleksibel tidak terbatas dengan waktu. Diperkuat dengan hasil jawaban responden dari siswa mengenai siswa dapat mengatur waktu untuk mengerjakan tugas secara daring mata pelajaran kewirausahaan sebesar $67,5 \%$ dengan kriteria tinggi. Dan siswa tidak didampingi saat pembelajaran kewirausahaan secara daring sebesar $49 \%$ dengan kriteria rendah.

Siswa mudah memahami materi kewirausahaan yang diajarkan oleh guru secara daring. Diperkuat dengan hasil jawaban responden dari siswa mengenai materi kewirausahaan yang diajarkan oleh guru secara daring mudah untuk dipahami sebesar $66 \%$ dengan kriteria tinggi. Siswa merasa bosan saat pembelajaran kewirausahaan daring berlangsung sebesar sebesar 49,5\% dengan kriteria rendah. Siswa malas saat pembelajaran kewirausahaan secara daring sebesar 45,5\% dengan kriteria rendah. Siswa kelas 12 SMK YPPM Boja tidak dapat konsentrasi saat pembelajaran kewirausahaan secara daring sebesar 49,5\% dengan kriteria rendah. Guru dan siswa dituntut harus siap melaksanakan pembelajaran kewirausahaan secara daring, walau sebetulnya tidak siap melaksanakan pembelajaran kewirausahaan secara daring. Diperkuat dengan hasil jawaban responden dari siswa mengenai siswa siap saat pembelajaran kewirausahaan secara daring sebesar 48,5\% dengan kriteria rendah.

Dengan adanya pembelajaran kewirausahaan secara daring siswa memiliki sikap disiplin dan tanggung jawab atas tugasnya saat pembelajaran daring. Diperkuat dengan hasil jawaban responden dari siswa mengenai siswa setelah pembelajaran kewirausahaan secara daring saya memiliki kedisiplinan dan tanggung jawab sebesar $67,5 \%$ dengan kriteria tinggi. Kemudian dengan adanya pembelajaran kewirausahaan secara daring ini siswa tidak senang membaca buku, Diperkuat dengan hasil jawaban responden dari siswa sebesar 49,5\% dengan kriteria rendah. Namun dari hasil angket siswa menunjukan dapat mencari hal baru saat pembelajaran kewirausahaan daring dengan persentase sebesar $64,5 \%$ dengan kriteria tinggi.

Hambatan bagi siswa dalam pelaksanaan pembelajaran kewirausahaan secara daring adalah sebagai berikut: (1) Siswa tidak siap saat pembelajaran kewirausahaan daring, (2) Siswa tidak senang dan tidak tertarik saat pembelajaran kewirausahaan daring, (3) Siswa kurang paham media pembelajaran online, (4) Jaringan internet tidak memadai, (5) Sulit mencari sumber belajar, (6) Tidak didampingi saat pembelajaran kewirausahaan daring, (7) Siswa tidak dapat konsentrasi, (8) Siswa merasa malas, (9) Siswa merasa bosan saat pembelajaran kewirausahaan daring berlangsung, (10) Setelah pembelajaran kewirausahaan daring siswa tidak senang membaca buku.

Strategi dalam pelaksanaan pembelajaran kewirausahaan daring untuk mengurangi hambatan adalah guru melakukan home visit. Hom evisit adalah silaturahmi atau kunjungan guru kerumah siswa dan mengumpulkan siswa yang bertempat tinggal sesuai jadwal yang telah ditentukan. Home visit salah satu alternatif memecahkan kesulitan belajar siswa dan mengurangi tindakan kenakalan siswa. , tujuan diadakannya home visit, sebagai berikut: (1) Untuk mendapatkan informasi langsung terkait dengan data-data anak yang diperlukan sekolah, (2) Menggali informasi agar data diri siswa menjadi lengkap, akurat dan uptodate, (3) Untuk mencocokkan data yang ada di sekolah dengan kondisi riil yang terbaru melalui pengamatan, wawancara, (4) Memecah permasalahan siswa yang mengalami kesulitan belajar, (5) Melakukan klarifikasi siswa yang sama sekali tidak mengumpulkan tugas karena berbagai faktor, (6) Dan untuk berbagi informasi serta berbagai saran dan ide yang sangat bermanfaat sebagai tindak lanjut yang akan direncanakan ke depan. Home visit dapat memecahkan masalah siswa atau kesulitan siswa saat pembelajaran kewirausahaan secara daring. Tujuan diadakannya home visit ini diharapkan mampu mengefektifkan pembelajaran kewirausahaan secara daring.

Home visit dilaksanakan setiap dua minggu sekali perwilayah, sesuai jadwal yang sudah ditentukan. Daerah home visit antara lain yaitu Getas, Singorojo, Limbangan, Tambahsari, Cening, Kedungboto, Kertosari, Boja barat, Boja Timur, Marsiran, Ngadipurwo, Bubakan, Tambangan, Banyuringin, Pasigitan, Ngadirgo, Beringin, Ngaliyan, Kalipuru, Jomblang, Taruman, Meteseh, Trisobo, dan Ngadipiro. Dengan adanya homevisit dapat memperoleh informasi data, dapat memecahkan kesulitan belajar siswa dan mengurangi tindakan kenakalan siswa, siswa yang tidak menguasai media pembelajaran daring dapat menangkap pembelajaran secara visual dan audio, dan siswa yang tidak dapat mengirimkan atau mengumpulkan tugas melalui media pembelajaran daring dapat mengumpulkan saat guru melakukan kunjungan.

Keberhasilan yang dicapai melalui diadakannya home visit, sebagai berikut: (1) Berkurangnya tingkat permasalahan siswa saat pembelajaran daring, seperti siswa tidak paham media pembelajaran online, siswa sulit 
belajar saat pembelajaran, siswa tidak mengerjakan tugas saat pembelajaran daring, dll, (2) Memotivasi siswa dan orang tua untuk mendorong kegiatan pembelajaran daring siswa di rumah, (3) Memberikan informasi-informasi mengenai pembelajaran daring, (4) Membantu pertumbuhan dan perkembangan pribadi siswa, (5) Guru dapat memiliki nilai siswa dengan menilai siswa secara langsung saat home visit.

Strategi untuk mengurangi hambatan siswa dengan diadakannya homevisit menunjukan sangat efektif, dapat terlaksana dengan baik, mengurangi tindakan kenakalan siswa, membantu memecahkan kesulitan belajar siswa di rumah dan kesulitan guru yang dihadapi saat pembelajaran kewirausahaan secara daring. Strategi bagi penulis agar pembelajaran kewirausahaan secara daring dapat berjalan dengan lancar maka sebagai siswa harus menyiapkan fasilitas penunjang sebelum pembelajaran daring dimulai seperti kuota internet, Aplikasi penunjang, Laptop dan materi pelajaran. Jadwal harus disesuaikan jangan sampai pembelajaran secara daring dipakai untuk liburan, mengingat upaya dari pemerintah untuk meminimalisir risiko penyebaran virus corona.

Sebelum diadakanya pembelajaran daring, SMK YPPM sudah mengagendakan home visit yang dilakukan oleh guru BK. Home visit ini dilakukan untuk siswa yang sering melanggar peraturan sekolah lebih dari batas yang sudah ditentukan. Dengan dilakukannya pelaksanaan pembelajaran home visit dengan membentuk kelompok belajar dengan jadwal yang sudah ditentukan dari sekolah. Adanya home visit ini dapat terlaksana dengan baik, sangat efektif, sangat membantu mengurangi kesulitan-kesulitan siswa dan kesulitan guru yang dihadapi saat pembelajaran kewirausahaan secara daring.

\section{KESIMPULAN}

Penelitian ini bertujuan untuk mengetahui pelaksanaan pembelajaran kewirausahaan secara daring dalam menumbuhkan kesiapan berwirausaha, hambatan pembelajaran kewirausahaan secara daring dalam menumbuhkan kesiapan berwirausaha dan strategi pembelajaran kewirausahaan secara daring dalam menumbuhkan kesiapan berwirausaha. Berdasarkan hasil penelitian yang telah dilakukan maka dapat diambil beberapa kesimpulan sebagai berikut: (1) Proses pelaksanaan pembelajaran kewirausahaan daring yang berlangsung di SMK YPPM Boja menunjukan hasil yang tidak efektif. Hal ini dapat dilihat melalui hasil wawancara dan hasil angket dengan hasil ratarata siswa masih banyak mengalami hambatan. (2) Hambatan yang dialami saat pelaksanaan pembelajaran kewirausahaan daring bagi siswa adalah siswa tidak siap saat pembelajaran kewirausahaan daring, tidak senang saat pembelajaran kewirausahaan daring, tidak tertarik pembelajaran kewirausahaan daring, kurang paham media pembelajaran online, jaringan internet tidak memadai, sulit mencari sumber belajar, tidak didampingi saat pembelajaran kewirausahaan daring, siswa tidak dapat konsentrasi, siswa merasa malas, bosan saat pembelajaran kewirausahaan daring berlangsung dan setelah pembelajaran kewirausahaan daring siswa tidak senang membaca buku. Sedangkan hambatan dalam pelaksanaan pembelajaran kewirausahaan daring bagi guru adalah guru kesulitan mencari nilai siswa karena siswa banyak yang tidak mengumpulkan tugas. (3) Strategi untuk mengurangi hambatan saat pelaksanaan pembelajaran kewirausahaan daring adalah guru melakukan home visit. Menunjukkan hasil yang sangat efektif dan berjalan lancar karena mengurangi sangat membantu memecahkan kesulitan belajar siswa di rumah dan kesulitan guru yang dihadapi saat pembelajaran kewirausahaan secara daring.

Berdasarkan hasil penelitian dan mempertimbangkan kondisi yang terjadi, maka peneliti merekomendasikan beberapa saran sebagai perbaikan kualitas dari masalah yang diangkat dalam penelitian ini, antara lain: (1) Untuk seluruh siswa tingkatkan lagi menggunakan dan memanfaatkan media pembelajaran daring agar siswa lebih inovatif dan meningkatkan rasa tanggung jawab sebagai siswa (2) Siswa menerapkan kedisiplinan saat pembelajaran kewirausahaan daring agar siswa dapat mengikuti serta memperhatikan semua materi yang telah diberikan untuk memberikan nilai tanggung jawab yang sama kepada siswa baik disekolah maupun di rumah. (3) Perlunya diadakannya workshop/pelatihan secara daring untuk memberikan wawasan pengetahuan dan ketrampilan dalam mengembangkan pembelajaran kewirausahaan secara daring yang tepat. (4) Perlunya meningkatkan bantuan kuota pulsa internet kepada siswa.

\section{Ucapan Terima Kasih}

Penulis mengucapkan terimakasih kepada (1) Bapak/Ibu Dosen Fakultas Ekonomi Universitas Negeri Semarang yang telah memberikan ilmu pengetahuan sehingga penulis dapat menyelesaikan penelitian ini. (2) Dra. Sri Marhaenis Embarsari, Wakil Kurikulum SMK YPPM Boja yang telah memberikan ijin penelitian. (3) Ibu Oenawati, S. Pd, Guru Kewirausahaan SMK YPPM Boja yang telah membantu memberikan informasi dan mendampingi penelitian selama penelitian berlangsung. (4) Siswa dan siswi SMK YPPM Boja yang telah membantu memberikan data dan informasi selama penelitian hingga terselesainya penelitian ini.

\section{DAFTAR PUSTAKA}

[1] Badan Pusat Statistik. 2019. Jumlah Pengangguran Di Indonesia Tahun 2019. Badan Pusat Statistik.

[2] Sudrajat, 2012. Kiat Mengentaskan Pengangguran dan Kemiskinan Melalui Wirausaha. Jakarta: Bumi Aksara. 
[3] Suryana. 2013. Kewirausahaan: Pedoman, Praktis, Kiat dan Proses Menuju Sukses. Jakarta: Salemba Empat.

[4] Ropke. 2012. Kewirausahaan Pendekatan Karakteristik Wirausaha Sukses. Yogyakarta: Graha Ilmu.

[5] Slamet, Tunjungsari; Mei le. 2014. Dasar-dasar Kewirausahaan: Teori dan Praktik. Jakarta: Indeks.

[6] Astiti, Yunita W. 2014. Pengaruh Pendidikan Kewirausahaan terhadap Motivasi Berwirausaha dan Keterampilan Berwirausaha Mahasiswa Pendidikan Ekonomi Universitas Negeri Yogyakarta. Skripsi UNY: Tidak Diterbitkan.

[7] Frinces, Heflin, 2011. Be An Entrepreneur. Yogyakarta: Graha Ilmu.

[8] Paramita, Dinda Trisna 2017. Pembelajaran Kewirausahaan Berbasis Alam. Skripsi UNNES: Tidak Diterbitkan.

[9] Indriana, Dina. 2011. Ragam Alat Bantu Media Pengajaran. Yogjakarta: DIVA Press.

[10] Numiek. 2013. Keefektifan e-learning sebagai media pembelajaran. Jurnal Pendidikan Vokasi No. 1 Vol. 3.

[11] Badan Pusat Statistik. 2018. Jumlah SMK di Jawa Tengah 2018. Badan Pusat Statistik.

[12] Fithra, Herman. 2020. Covid-19 dan Pembelajaran Daring. (Diunduh Tanggal 26 Maret 2020). https://mediaindonesia.com/opini/298964/covid-19-dan-pembelajaran-daring. 